\title{
Spontaneous Pneumothorax in Severe COVID-19 Pneumonia: Interventional Treatment and Risk of Transmission
}

\author{
Ağır COVID-19 Pnömonisinde Spontan Pnömotoraks: Girişimsel Tedavi ve \\ Bulaşma Riski
}

Mia Elhidsi, Prasenohadi, Dicky Soehardiman

\section{Abstract}

Severe Acute Respiratory Syndrome Coronavirus 2 (SARS-CoV2), or Coronavirus disease 2019 (COVID19), is a highly contagious and rapidly-spreading disease. While pneumonia is a common finding, pleural space involvement, such as pneumothorax, occurs only in rare cases. Pneumothorax requires the immediate insertion of a chest tube. Thoracostomy procedures require prompt and precise management, but with caution to avoid the risk of transmission. We report here on a 49-year-old male patient who was admitted to the emergency ward with shortness of breath and oxygen desaturation. A physical examination and portable chest $X$-ray indicated a left pneumothorax. The patient underwent tracheal intubation followed by chest tube insertion, and the lungs inflated two hours after the procedure. The operators included two people, wearing personal protective equipment (PPE), including N95 masks, full eye protection, a face shield and a fluid-resistant gown. Two weeks following chest tube insertion, the operators underwent a SARS-CoV2 PCR examination, with negative results. This report discusses relevant findings in literature related to the current issue.

Key words: Pneumothorax, COVID19, chest tube, thoracostomy, risk of transmission.

\section{Özet}

Ağır Akut Solunum Sendromu Corona Virüs 2 (SARSCoV2) veya Corona Virüs Hastalığı 2019 (COVID19), yüksek bulaşıcılığı olan ve hızla yayılan bir hastalıktır. Pnömoni sık görülürken, pnömotoraks gibi plevral boşluğun tutulumu nadir olarak meydana gelir. Pnömotoraks hemen bir toraks tüpü takılmasını gerektirir. Torakostomi işlemleri hassas ve hızlı bir yönetim gerektir, ancak bulaşma riskinden kaçınmak için dikkat edilmelidir. Acil servise nefes darlığı ve oksijen desatürasyonu ile gelen 49 yaşındaki bir erkek hastayı sunuyoruz. Fizik muayene ve portabl akciğer grafisinde solda pnömotoraks saptandı. Hastaya trakeal entübasyonu takiben toraks tüpü takıldı ve işlem sonrası iki saatte akciğerler ekspanse oldu. N95 maskeleri, tam göz koruması, yüz siperi ve sıvıya dayanıklı önlük dahil kişisel koruyucu ekipman (PPE) giyen iki cerrah işlemi yaptı. Toraks tüpü takılmasından iki hafta sonar cerrahların SARS-Cov2 PCR testleri negatif olarak geldi. Bu yazıda, konu ile ilgili güncel literatürlerle mevcut bulgular tartışıldı.

Anahtar Sözcükler: Pnömotorkas, COVID 19, toraks tüpü, torakostomi, bulaşma riski.
Division of Pulmonary Intervention and Pulmonary Emergency, the Department of Pulmonology and Respiratory Medicine, Faculty of Medicine, Universitas Indonesia - Persahabatan National Respiratory Referral Hospital, Jakarta, Indonesia
Pulmoner Müdahale ve Akciğer Acilleri Bölümü, Göğüs Hastalıkları ve Solunum Tıbbı Bölümü, Tıp Fakültesi, Universitas Endonezya - Persahabatan Ulusal Solunum Yönlendirme Hastanesi, Jakarta, Endonezya

Submitted (Başvuru tarihi): 18.06.2020 Accepted (Kabul tarihi): 28.08.2020

Correspondence (iletişim): Mia Elhidsi, Division of Pulmonary Intervention and Pulmonary Emergency, the Department of Pulmonology and Respiratory Medicine, Faculty of Medicine, Universitas Indonesia - Persahabatan National Respiratory Referral Hospital, Jakarta, Indonesia

e-mail: mia.elhidsi@gmail.com

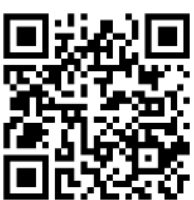


COVID19 is an infectious disease that primarily affects the respiratory system. First identified in Wuhan, China at the end of 2019, the condition spread globally, resulting in a global pandemic. Although most cases are mild and asymptomatic, the mortality risk is quite high in severe cases. The most commonly noted symptoms are cough, fatigue, phlegm, shortness of breath, myalgia, sore throat and headache $(1,2)$. Typical radiological findings are bilateral multilobular ground-glass opacities (GGO) with predominance in the peripheral and posterior areas (3). Pneumothorax as a clinical manifestation is rare. We report here on a thoracostomy chest tube insertion procedure on a patient with severe COVID19 complicated with pneumothorax and pneumomediastinum, and the subsequent follow-up PCR analysis of the assigned operators.

\section{CASE}

A 49-year-old male was admitted to the emergency room (ER) with progressive shortness of breath for the two days prior to admission. The patient complained of continuously tightness of the chest that was not induced by activity. There was no chest pain or fever for three days, and only rare coughing. The patient was conscious and with a respiratory rate of 34/minute; blood pressure, 130/90 $\mathrm{mmHg}$; heart rate, 102/min; and oxygen saturation, 70\% room air. The patient is a smoker, but with no comorbid factors. A physical lung examination revealed decreased breathing sounds in the left hemithorax accompanied by crepitations in the left hemithorax and neck. Blood examination WBC, 10.7 103/uL; Neu lymphocyte, 91.2\%; HGB, $14.2 \mathrm{~g} / \mathrm{dL}$; HCT, 40.0\%; PLT, 142 103/uL; blood glucose, $173 \mathrm{mg} / \mathrm{dL}$; urea, $234 \mathrm{mg} / \mathrm{dL}$; Creatinine, 14.0 $\mathrm{mg} / \mathrm{dL} ;$ ALT (SGPT), $43 \mathrm{U} / \mathrm{L}$; AST (SGOT), $74 \mathrm{U} / \mathrm{L}$; CRP, $115 \mathrm{mg} / \mathrm{L}$; and procalcitonin, $1.91 \mathrm{ng} / \mathrm{ml}$. Blood gas analysis, $\mathrm{pH}: 7.28 ; \mathrm{pCO}_{2}, 20.10 \mathrm{mmHg} ; \mathrm{pO}_{2}, 43.70$ $\mathrm{mmHg} ; \mathrm{HCO}_{3}, 9.70 \mathrm{mmHg}$; and $\mathrm{SaO}_{2}, 73.70 \%$. A radiograph and chest $\mathrm{X}$-ray using portable machines reveled pleural lines in the left hemithorax.

The patient's severe respiratory distress led to intubation and invasive mechanical ventilation. A chest $X$-ray suggested progressing pneumothorax. The patient had chest tube inserted (thoracostomy) into the left chest using a $28 \mathrm{Fr}$ tube connected into the pleural drainage system in a negative-pressure room (Figure 1). Initially, a $10-\mathrm{cm}$ undulation presenting with bubbles without fluid production was observed. The team comprised two members, i.e., one operator and one assistant, using protective equipment, including as fluid-resistant gown, safety goggles, gloves and N95 masks (Figure 2).

Following the chest tube insertion, oxygen saturation rose to $90 \%$ with a $100 \%$ fraction of inspired oxygen. A chest $X$-ray repeated two hours after the procedure revealed an inflating left lung. The medical team was evaluated two weeks after the procedure. Both they had no respiratory symptoms, and PCR analyses of nasopharynx swabs were negative for SARS-CoV2.

\section{DISCUSSION}

Pneumothorax is a rarely-encountered COVID19 complication $(3,4)$. Studies in Wuhan reported that only 1 of 99 COVID19 patients experienced pneumothorax (4). A literature review was made of three databases, namely PubMed, ScienceDirect and Cochrane, on June 10, 2020. Medical subject headings (MesH terms) and text words in the title or abstracts were used to search the two subjects of interest, i.e., population and intervention. Both keywords were combined with Boolean operators such as "and" and "OR". We avoided restrictions on language or article type, while averted is findings on unpublished articles and incorrect manuscripts. We obtained four case reports related to a total of 5 patients (Table 1). The majority of patients were male, in line with the gender distribution of those with COVID19 in general (5-8). Found literature reported left thoracic pneumothorax, but provided no biological or plausible explanation. No dominant side was noted to be affected by pneumothorax during the severe acute respiratory syndrome (SARS) outbreak in $2003(9,10)$.

Pneumothorax is an emergency necessitating immediate management. As with other etiologies, a pneumothorax complicating COVID19 requires thoracostomy. In the case of tension pneumothorax, emergency measures involving needle chest decompression are necessary. The lung may re-inflate in a few hours or in up to two weeks. In different settings, pneumothorax may happen following the extensive use of a mechanical ventilator, in which excessive pressure and volumes become disruptive. In such cases, when accompanied by a persistent air leak, the optimum outcome will require an invasive procedure, i.e., thoracoscopy (8). 

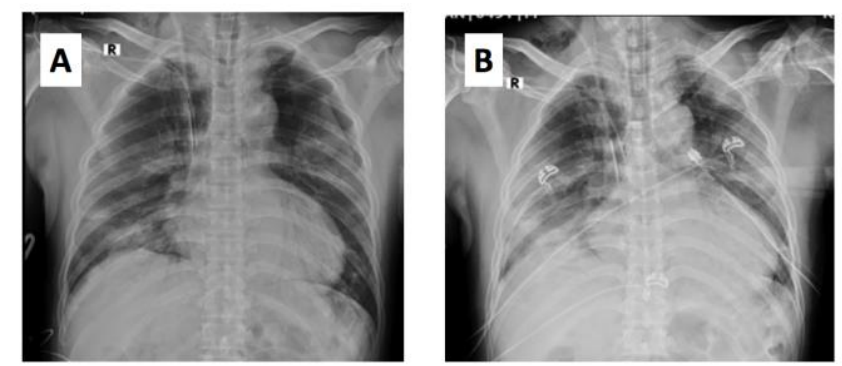

Figure 1: Chest X-ray of a left pneumothorax before and after chest tube insertion. A left pneumothorax, left-sided pleural line, subcutaneous emphysema (A), Chest tube insertion, expanded left lung (B)

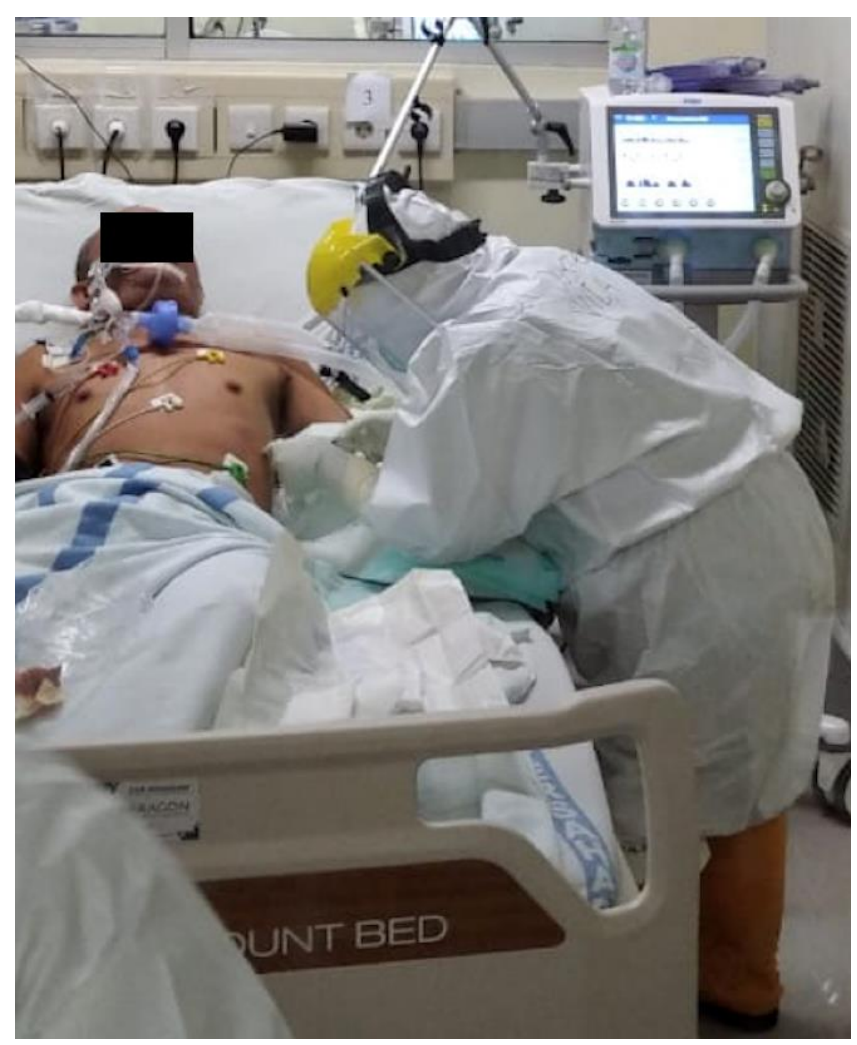

Figure 2: Operator's personal protective equipment: N95, full eye protection, face shield, gloves and fluid-resistant gown

Even though current evidence fails to observe SARSCOV2 aerosolization through the inserted chest tube, there is a potential contamination risk through a chest drain air leak. It is reasonable, therefore, to perform a thoracostomy in a negative pressure airborne infection isolation room (AlIR). When no AllR is available, entering the room within 10 minutes of the procedure should be avoided (11). The prevention of transmission is achievable through adequate room preparation, the minimization of the assigned personnel and the use of personal protective equipment (at minimum, an N95 mask, full eye protection, face shield and a fluid-resistant gown). A suction wall and a virus filter may minimize chest drain-mediated droplet exposure $(12,13)$.

\section{CONCLUSION}

Severe COVID-19 infection proceeds rapidly, according to the clinical finding and chest CT findings, although no effective drug has yet been identified. In such situations, the use of glucocorticosteroids may be clinically useful. The number of patients continues to increase worldwide, while data on the treatment and prognosis of the disease are still insufficient. Further research is warranted in the future.

\section{CONFLICTS OF INTEREST}

None declared.

\section{AUTHOR CONTRIBUTIONS}

Concept - M.E., P., D.S.; Planning and Design - M.E., P., D.S.; Supervision - M.E., P., D.S.; Funding - M.E., P., D.S.; Materials - M.E., P., D.S.; Data Collection and/or Processing - M.E., P., D.S.; Analysis and/or Interpretation - M.E., P., D.S.; Literature Review - M.E., P., D.S.; Writing - M.E., P., D.S.; Critical Review - M.E., P., D.S.

\section{YAZAR KATKILARI}

Fikir - M.E., P., D.S.; Tasarım ve Dizayn - M.E., P., D.S.; Denetleme - M.E., P., D.S.; Kaynaklar - M.E., P., D.S.; Malzemeler - M.E., P., D.S.; Veri Toplama ve/veya İşleme - M.E., P., D.S.; Analiz ve/veya Yorum - M.E., P., D.S.; Literatür Taraması - M.E., P., D.S.; Yazıyı Yazan - M.E., P., D.S.; Eleştirel İnceleme - M.E., P., D.S.

\section{REFERENCES}

1. Wu Z, McGoogan JM. Characteristics of and Important lessons from the coronavirus disease 2019 (COVID-19) outbreak in China: summary of a report of 72 of 314 cases from the Chinese Center for Disease Control and Prevention. JAMA 2020; 323:1239-42. [CrossRef]

2. Zhou F, Yu T, Du R, Fan G, Liu Y, Liu Z, et al. Clinical course and risk factors for mortality of adult inpatients with COVID-19 in Wuhan, China: a retrospective cohort study. Lancet 2020; 395:1054-62. [CrossRef]

3. Salehi S, Abedi A, Balakrishnan S, Gholamrezanezhad A. Coronavirus disease 2019 (COVID-19): a systematic review of imaging findings in 919 patients. AJR Am J Roentgenol 2020; 14:1-7. [CrossRef]

4. Chen N, Zhou M, Dong X, Qu J, Gong F, Han Y, et al. Epidemiological and clinical characteristics of 99 cases of 2019 the novel coronavirus pneumonia in Wuhan, China: a descriptive study. Lancet 2020; 395:507-13. [CrossRef] 
5. Flower L, Carter JL, Rosales Lopez J, Henry AM. Tension pneumothorax in a patient with COVID-19. BMJ Case Rep 2020; 13:e235861. [CrossRef]

6. Ucpinar BA, Sahin C, Yanc U. Spontaneous pneumothorax and subcutaneous emphysema in COVID-19 patient: Case report. J Infect Public Health 2020; 13:887-9. [CrossRef]

7. Aydin S, Oz G, Dumanli A, Balci A, Gencer A. A case of spontaneous pneumothorax in Covid-19 of Pneumonia. J Surg Res 2020; 3:96-101. [CrossRef]

8. Aiolfi A, Biraghi T, Montisci A, Bonitta G, Micheletto G, Donatelli $F$, et al. Management of persistent pneumothorax with thoracoscopy and blebs resection in COVID-19 patients. Ann Thorac Surg 2020; 110:e413-5. [CrossRef]

9. Kao HK, Wang JH, Sung CS, Huang YC, Lien TC. Pneumothorax and mortality in the mechanically ventilated SARS patients: a prospective clinical study. Critical Care 2005; 9:R440-5. [CrossRef]

10. Sihoe ADL, Wong RHL, Lee ATH, Lau LS, Leung NYY, Law Kl, et al. Severe acute respiratory syndrome compli- cated by spontaneous pneumothorax. Chest 2004; 125:2345-51. [CrossRef]

11. Van Doremalen N, Bushmaker T, Morris DH, Holbrook MG, Gamble A, Williamson BN, et al. Aerosol and surface stability of SARS-CoV-2 as compared with SARSCoV-1. N Engl J Med 2020; 382:1564-7. [CrossRef]

12. The British Thoracic Society Pleural Disease Guideline Group. BTS Pleural Disease Guideline 2010. The British Thoracic Society. Available at https://www.britthoracic.org.uk/document-library/qualityimprovement/covid-19/pleural-services-during-covid-19pandemic/. 2010; Accessed: June 9, 2020.

13. Pieracci FM, Burlew CC, Spain D, Livingston DH, Bulger EM, Davis KA, et al. Tube thoracostomy during the COVID-19 pandemic: guidance and recommendations from the AAST Acute Care Surgery and Critical Care Committees. Trauma Surg Acute Care Open 2020; 5:e000498. [CrossRef] 